\title{
ODONTOCETE SIGHTINGS COLLECTED DURING OFFSHORE CRUISES IN THE WeSTERN AND SOUTHWESTERN CARIBbean SEA ${ }^{1}$
}

\author{
Mario A. Pardo ${ }^{2}$, Angélica Mejía-Fajardo ${ }^{3,4}$, Sandra Beltrán-Pedreros ${ }^{5}$, \\ Fernando Trujillo ${ }^{6}$, IAin KerR ${ }^{7}$ and Daniel M. Palacios ${ }^{8,9},{ }^{*}$
}

While the cetacean fauna of the eastern Caribbean Sea (i.e. the Greater Antilles, the Lesser Antilles and Venezuela) is reasonably well known (e.g. Erdman et al., 1973; Taruski and Winn, 1976; Mignucci-Gianonni, 1998; Romero et al., 2001; 2002; Swartz et al., 2003; Acevedo-Galindo, 2007), portions of the western and southwestern regions remain virtually unexplored. Here we present 14 odontocete sightings made during four offshore cruises in Colombian and Panamanian waters spanning the period 1988-2008. Observations of the spinner dolphin (Stenella longirostris), the false killer whale (Pseudorca crassidens) and the sperm whale (Physeter macrocephalus) are the first for these areas.

Two cruises over continental shelf and slope waters of the southwestern Caribbean were conducted in 1988 and 1994 through a collaboration between American and Colombian organizations. The purpose of these cruises was to provide training in cetacean research techniques to local scientists, with a focus on sperm whale acoustic tracking using towed hydrophone arrays. The two cruises employed similar vessels (sailboats) and followed similar routes. The Caribbean leg of the 'Expedición Siben' took place between 12-15 May 1988 aboard the 27m R/V Siben, covering $698.7 \mathrm{~km}$ between Cartagena, Colombia, and Colón, Panamá (Torres et al., 1988 ${ }^{10}$; Figure 1c). The second cruise took place between 23-28 April 1994 aboard the $28 \mathrm{~m} \mathrm{R} / \mathrm{V}$ Odyssey, covering $462.4 \mathrm{~km}$ along the route Colón-Cartagena (Figure 1c). On both cruises, two observers maintained visual watches during daylight hours (07:00-18:00h, weather permitting), using the naked eye or hand-held binoculars. On the Siben the observation was conducted from the bow and the stern (3-4m above the waterline), while on the Odyssey observers were positioned atop the ship's pilothouse (4m above the waterline) and in the crow's nest on the main mast (18m above the waterline). Whenever possible, cetacean groups were approached to confirm species identification and group size, either by the sailing vessel or using auxiliary inflatable boats.

The other two cruises were organized by the Dirección General Marítima de Colombia (DIMAR), through its Centro de Investigaciones Oceanográficas e Hidrográficas (CIOH) aboard the $50.9 \mathrm{~m}$ R/V Malpelo. The $\mathrm{CIOH}$ conducts oceanographic surveys in Colombian waters on a regular basis, and for these cruises it invited marine mammal biologists to use the vessel as a platform of opportunity. One took place in waters of the San Andrés, Providencia and the Cays Archipelago, western Caribbean, between 6-13 August 1990. Its objective was to carry out a hydroacoustic assessment in waters of the archipelago using a fisheries echosounder along a predetermined $1607.2 \mathrm{~km}$ track (Beltrán-Pedreros, 199011; Figure 1b). During daylight hours (06:00-19:00h), one observer searched for cetaceans from the ship's flying bridge $10 \mathrm{~m}$ above the waterline with the aid of hand-held binoculars. Since sightings were not closed on, only cetacean groups that occurred near the ship could be identified and counted. The other cruise was carried out off the central Colombian coast between 10-25 August 2008. Its main purpose was to collect oceanographic and biochemical data along the groundtrack of the altimetric satellite JASON-1 (Figure 1d). Searching for cetaceans was conducted from Malpelo's flying bridge by three observers who looked toward the bow, port and starboard sectors, respectively (Mejía-Fajardo, 2009). Due to logistical constraints, search effort was divided into $20 \mathrm{~min}$ intervals, alternating between on and off periods (Figure 1d).

\footnotetext{
${ }^{1}$ Received on 11 April 2010. Acepted on 2 June 2010. Managed by Karina Acevedo-Whitehouse.

2 Centro de Investigación Científica y de Educación Superior de Ensenada (CICESE) - Unidad La Paz, Miraflores 334, La Paz, BCS 23050, México.

${ }^{3}$ Universidad Jorge Tadeo Lozano, Facultad de Ciencias Naturales, Carrera 2 No. 11-68, El Rodadero, Santa Marta, Colombia.

${ }^{4}$ Current address: Centro de Investigaciones Oceanográficas e Hidrográficas (CIOH), Área de Oceanografía Operacional, Escuela Naval de Cadetes 'Almirante Padilla', Barrio El Bosque, Sector Manzanillo, Cartagena, Colombia.

${ }^{5}$ Universidad UNILASALLE-Manaus, Rua Ajuriaca, 361, Bairro Aleixo, 69.083-020, Manaus, AM, Brasil.

${ }^{6}$ Fundación Omacha, Calle 86A No. 23-38, Bogotá DC, Colombia.

${ }^{7}$ Ocean Alliance, 191 Weston Road, Lincoln, MA 01773, USA.

${ }^{8}$ Joint Institute for Marine and Atmospheric Research, University of Hawaii, 1000 Pope Road, MSB 312, Honolulu, HI 96822, USA.

${ }^{9}$ NOAA, NMFS, Southwest Fisheries Science Center, Environmental Research Division, 1352 Lighthouse Avenue, Pacific Grove, CA 93950-2097, USA.

Corresponding author, e-mail: Daniel.Palacios@noaa.gov.

${ }^{10}$ Torres, F., Obregón, C. and Trujillo, F. (1988) Expedición Siben en costas colombianas. Interpolar Research Society and Long-term Research Institute, Lincoln, MA, USA. Unpublished report. 12p. [Available from the authors].

${ }^{11}$ Beltrán-Pedreros, S. (1990) Avistamiento de mamíferos marinos en el Caribe Colombiano, área de San Andrés, Providencia y Los Cayos. Centro de Investigaciones Oceanográficas e Hidrológicas, Cartagena, Colombia. Unpublished report. 10pp. [Available from the authors].
} 


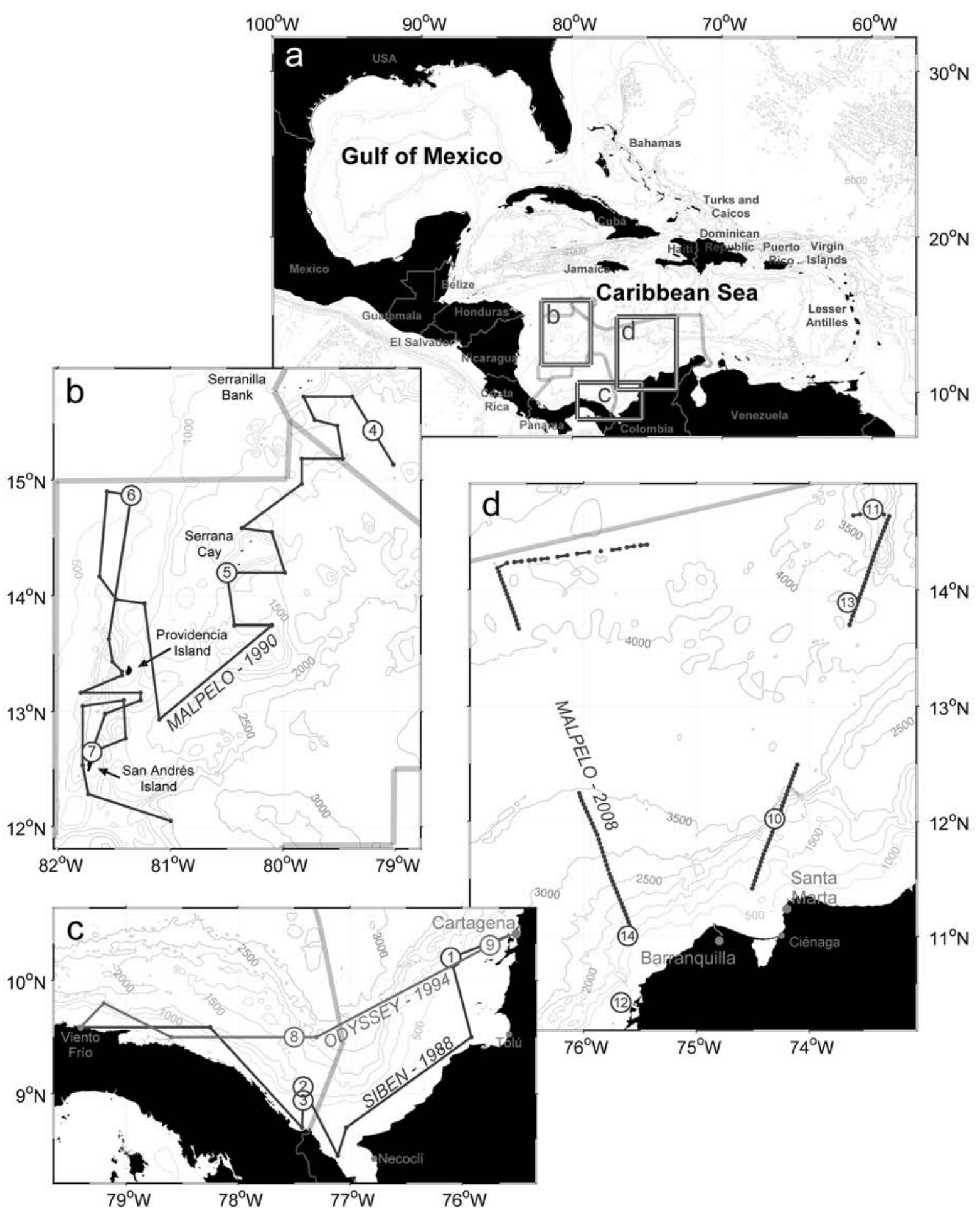

Figure 1. (a) Map of the Caribbean Sea showing the areas where the cruises took place. Insets: tracks and cetacean sightings in the western and southwestern Caribbean during the (b) Malpelo-1990, (c) Siben-1988 and Odyssey-1994, and (d) Malpelo-2008 cruises, respectively. Sighting locations are shown as circles with numbers corresponding to those in Table 1. The limits of the Colombian and Panamanian Exclusive Economic Zones (EEZ) (source: VLIZ, 2009'12; striped lines) and selected bathymetric contours (source: SRTM30_PLUS global topography v.6.0, available from <http:// topex.ucsd.edu/>) are also shown.

${ }^{12}$ VLIZ (2009) Maritime Boundaries Geodatabase - World EEZ Version 5.0. Flanders Marine Institute. [Available online from the Flanders Marine Institute, Ostend, Belgium, <http:/ /www.vliz.be/vmdcdata/marbound>, consulted on 8 October 2009]. 
Fourteen sightings of six odontocete species were collected during the four cruises: Atlantic spotted dolphins (Stenella frontalis), pantropical spotted dolphins (Stenella attenuata), common bottlenose dolphins (Tursiops truncatus), spinner dolphins (Stenella longirostris), false killer whales (Pseudorca crassidens) and sperm whales (Physeter macrocephalus) (Table 1). A medium-sized group (30-40 animals) of spinner dolphins was sighted during the Siben cruise in May 1988 in Panamanian waters. The sighting occurred at a depth of $548 \mathrm{~m}$ over the continental slope (Table 1, Figure 1). The species is known from several sightings and strandings in the eastern Caribbean around Curaçao, Puerto Rico, St. Vincent, the Virgin Banks, Dominica, St. Lucia, and Venezuela (Caldwell et al., 1971; Erdman et al., 1973; Taruski and Winn, 1976; Jefferson and Lynn, 1994; Romero et al., 2001; 2002), but this one is the first record for the southwestern Caribbean.

Two sperm whale sightings were made during these cruises: the first one was a group of ten individuals in $441 \mathrm{~m}$ water near San Andrés Island, during the Malpelo cruise in August 1990, while the second one was a group of eight individuals, including two calves, in Panamanian waters during the Odyssey cruise in April 1994. This group occurred near the Colombian border over a submarine ridge in $1578 \mathrm{~m}$ waters (Table 1, Figure 1c). A photograph of an animal's fluke was taken and submitted to the North Atlantic and Mediterranean Sperm Whale Catalogue (NAMSC, catalogue numbers: WCI-1994-376-14, WCI1994-376-15, and WCI-1994-376-16) (Figure 2). Sperm whales were also heard on the Siben's hydrophones off Barranquilla, prior to the ship's arrival to Cartagena. These are the first records of the species in the western and southwestern Caribbean and it is uncertain whether these animals belong to either of the better-known populations of the eastern Caribbean (Gordon et al., 1998; Gero et al., 2007) or the Gulf of Mexico (Weller et al., 2000), or whether they are their own entity (no matches were found with the NAMSC).

False killer whales were sighted during the Malpelo cruise in August 1990 close to Serrana Cay, to the northeast of Providencia Island, in $798 \mathrm{~m}$ water (Table 1, Figure 1). This is the first record of the species for Colombian waters and for the western Caribbean. Three subsequent sightings have been recently reported along the continental coast near Santa Marta and in the Tayrona National Natural Park (Fraija et al., 2009), and a stranding of a single animal occurred in the nearby Santuario de Fauna y Flora Los Flamencos in June 2001 (Pardo et al., 2009). The species is better known from the eastern Caribbean, where it prefers deep waters around oceanic islands (Mignucci-Gianonni, 1998). In the Gulf of Mexico it has

Table 1. Cetacean sighting information collected during the Siben, Malpelo, and Odyssey cruises in the western and southwestern Caribbean between 1988 and 2008.

\begin{tabular}{|c|c|c|c|c|c|c|c|}
\hline \multirow[t]{2}{*}{ SIGHTING* } & \multirow[t]{2}{*}{ SPECIES } & \multicolumn{2}{|c|}{ GROUP SIZE } & \multicolumn{2}{|c|}{ POSITION } & \multirow[t]{2}{*}{ DEPTH $(\mathrm{m})^{* *}$} & \multirow[t]{2}{*}{ DATE } \\
\hline & & Min. & Max. & Longitude & Latitude & & \\
\hline \multicolumn{8}{|c|}{ R/V Siben: $698.65 \mathrm{~km}$} \\
\hline 1 & Stenella frontalis & 12 & 17 & $76^{\circ} 06^{\prime} 00^{\prime \prime} \mathrm{W}$ & $10^{\circ} 12^{\prime} 00^{\prime \prime} \mathrm{N}$ & 1234 & $12 / 5 / 1988$ \\
\hline 2 & Tursiops truncatus & 3 & 3 & $77^{\circ} 25^{\prime} 12^{\prime \prime} \mathrm{W}$ & $9^{\circ} 03^{\prime} 36^{\prime \prime} \mathrm{N}$ & 1241 & $15 / 5 / 1988$ \\
\hline 3 & Stenella longirostris & 30 & 40 & $77^{\circ} 25^{\prime} 12^{\prime \prime} \mathrm{W}$ & $8^{\circ} 56^{\prime} 02^{\prime \prime} \mathrm{N}$ & 548 & $15 / 5 / 1988$ \\
\hline \multicolumn{8}{|c|}{ R/V Malpelo: $1607.20 \mathrm{~km}$} \\
\hline 4 & Stenella attenuata & 300 & 400 & $79^{\circ} 12^{\prime} 00^{\prime \prime} \mathrm{W}$ & $15^{\circ} 25^{\prime} 30^{\prime \prime} \mathrm{N}$ & 2283 & $6 / 8 / 1990$ \\
\hline 5 & Pseudorca crassidens & 3 & 4 & $80^{\circ} 30^{\prime} 00^{\prime \prime} \mathrm{W}$ & $14^{\circ} 12^{\prime} 00^{\prime \prime} \mathrm{N}$ & 798 & $7 / 8 / 1990$ \\
\hline 6 & Tursiops truncatus & 35 & 40 & $40^{\circ} 81^{\prime} 00^{\prime \prime} \mathrm{W}$ & $14^{\circ} 52^{\prime} 00^{\prime \prime} \mathrm{N}$ & 436 & 9/8/1990 \\
\hline 7 & Physeter macrocephalus & 10 & 10 & $81^{\circ} 42^{\prime} 00^{\prime \prime} \mathrm{W}$ & $12^{\circ} 39^{\prime} 00^{\prime \prime} \mathrm{N}$ & 441 & $11 / 8 / 1990$ \\
\hline \multicolumn{8}{|c|}{ R/V Odyssey: $462.39 \mathrm{~km}$} \\
\hline 8 & Physeter macrocephalus & 8 & 8 & $77^{\circ} 30^{\prime} 00^{\prime \prime} \mathrm{W}$ & $9^{\circ} 30^{\prime} 00^{\prime \prime} \mathrm{N}$ & 1578 & $27 / 4 / 1994$ \\
\hline 9 & Tursiops truncatus & 2 & 2 & $75^{\circ} 45^{\prime} 00^{\prime \prime} \mathrm{W}$ & $10^{\circ} 18^{\prime} 26^{\prime \prime} \mathrm{N}$ & 161 & 28/4/1994 \\
\hline \multicolumn{8}{|c|}{ R/V Malpelo: $318.47 \mathrm{~km}$ (effective effort) } \\
\hline 10 & Stenella frontalis & 10 & 20 & $74^{\circ} 17^{\prime} 14^{\prime \prime}$ & $12^{\circ} 00^{\prime} 14^{\prime \prime}$ & 2162 & $11 / 8 / 2008$ \\
\hline 11 & Unidentified dolphin & 7 & 11 & $73^{\circ} 24^{\prime} 21^{\prime \prime}$ & $14^{\circ} 40^{\prime} 15^{\prime \prime}$ & 2208 & $12 / 8 / 2008$ \\
\hline 12 & Tursiops truncatus & 4 & 6 & $75^{\circ} 37^{\prime} 32^{\prime \prime}$ & $10^{\circ} 24^{\prime} 13^{\prime \prime}$ & 96 & $15 / 8 / 2008$ \\
\hline 13 & Unidentified dolphin & 1 & 1 & $73^{\circ} 38^{\prime} 16^{\prime \prime}$ & $13^{\circ} 50^{\prime} 33^{\prime \prime}$ & 4002 & $23 / 8 / 2008$ \\
\hline 14 & Tursiops truncatus & 45 & 50 & $75^{\circ} 32^{\prime} 46^{\prime \prime}$ & $10^{\circ} 59^{\prime} 12^{\prime \prime}$ & 1029 & $25 / 8 / 2008$ \\
\hline
\end{tabular}

${ }^{*}$ ) Sighting numbers correspond to those inside circles in Figure 1.

${ }^{* *}$ Source: SRTM30_PLUS global topography v.6.0, [Available from <http://topex.ucsd.edu/ >. 
been recorded mainly in summer, in groups ranging from 1 to 35 animals and in waters ranging in depth from 974 to 1091m (Jefferson, 1996; Mullin et al., 2004).

A medium-sized group (12-17 individuals) of Atlantic spotted dolphins was sighted near Cartagena during the Siben cruise in May 1988. The group occurred over a narrow slope in $1234 \mathrm{~m}$ waters (Figure 1c). A similarly sized group was sighted aboard R/V Malpelo in August 2008, to the north of Santa Marta, over the continental slope at a depth of $2162 \mathrm{~m}$ (Table 1, Figure $1 \mathrm{~b}$ ). This is one of the most frequently seen species in the Caribbean Sea (Perrin, 2002), inhabiting shallow coastal waters and the vicinity of oceanic islands (e.g. Jefferson and Lynn, 1994). It is also common throughout the continental coast of Colombia, often found in groups of 1-30 individuals (Pardo and Palacios, 2006).

A large group (300-400 animals) of pantropical spotted dolphins was sighted during the Malpelo cruise in August 1990 in oceanic waters of the western Caribbean, within the Colombia-Jamaica Joint Regime. The depth of this sighting $(2283 \mathrm{~m})$ was the greatest among all sightings collected during the four cruises (Table 1, Figure 1), and the size of this group is among the largest for the Caribbean Sea, since the average is around 34.8 individuals (MignucciGiannoni et al., 2003). Although there are only four previous records of the species for the Colombian Caribbean (Vidal, 1990; Jefferson and Lynn, 1994; Pardo and Palacios, 2006), it has been reported both in the eastern and western Caribbean (Jefferson and Lynn, 1994). In coastal waters off Venezuela and Colombia the groups are small (2-3 individuals)
(Romero et al., 2001; Pardo and Palacios, 2006).

The common bottlenose dolphin was sighted during all four cruises in small- to medium-sized groups of 2-50 animals. Locations included: near Cartagena, in Panamanian waters near the Colombian border, north of the San Andrés, Providencia and the Cays Archipelago, and off the central Colombian coast. The sightings occurred in depths ranging between 161 and $1241 \mathrm{~m}$ (Table 1, Figure 1). This species is commonly reported along the Colombian coast in groups of 2-20 individuals (Vidal, 1990; Flórez-González and CapellaAlzueta, 1995; Pardo and Palacios, 2006), and throughout the Caribbean Sea (Grigg and Markowitz, 1997; Kerr et al., 2005; Romero et al., 2001). Off the central coast of Venezuela groups average 14.7 and range from 4-30 individuals (Bolaños-Jiménez et al., 2007³).

This note documents some of the earliest (as well as more recent) efforts to conduct marine mammal research in the Colombian Caribbean, a region that has not received much attention from the scientific community. The cruises presented here were exploratory in nature and were not designed as surveys for estimating abundance. Except for the Malpelo cruise in 2008, important information such as the time of start and end of the observation periods, the sea state and weather conditions, and the segments of track covered at nighttime was not recorded or is missing. Nevertheless, the sighting data collected during the cruises has proved to be valuable for documenting species occurrence in the western and southwestern portions of the Caribbean, where minimal or no information is available (Ward et al., 2001). Further, these cruises have provided invaluable

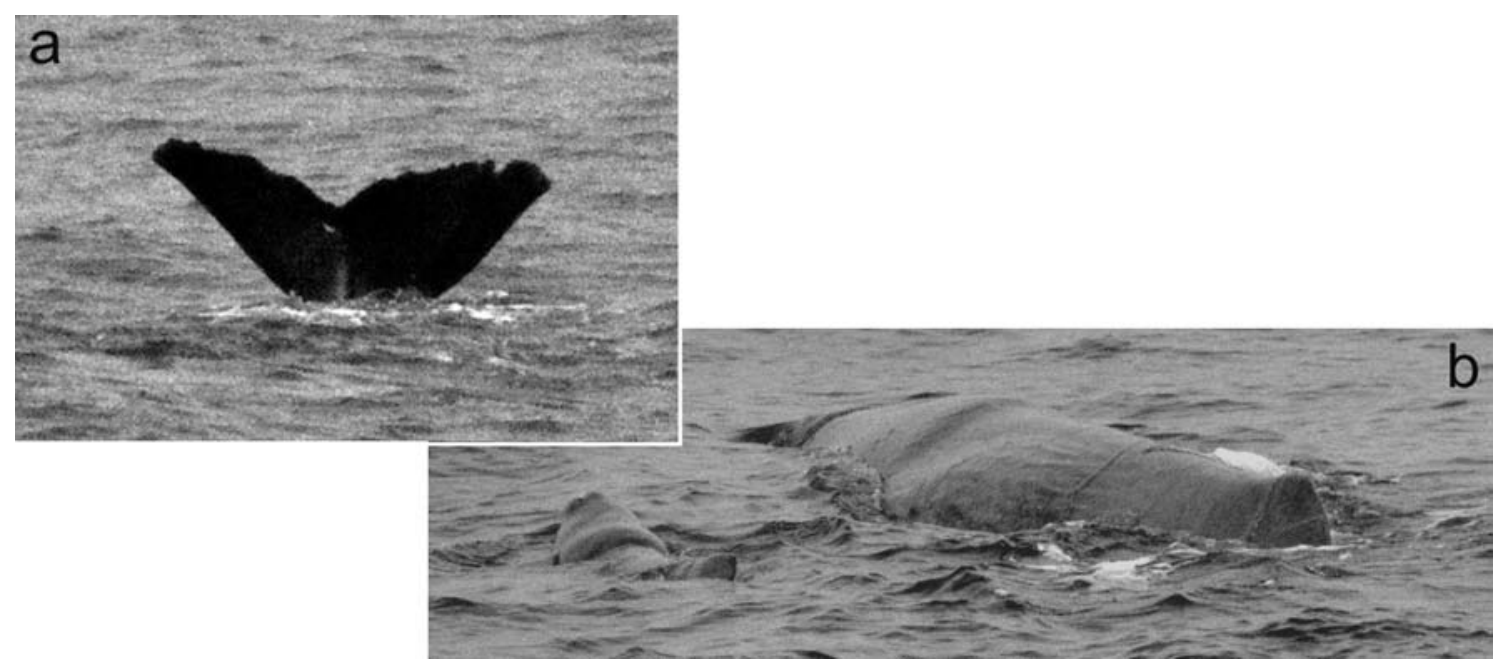

Figure 2. Photographs of a sperm whale sighting taken during the Odyssey cruise in 1994. (a) The distinctive fluke of one of the individuals in the group (NAMSC catalog number WCI-1994-376-15). (b) An adult-calf pair.

\footnotetext{
${ }^{13}$ Bolaños-Jiménez, J., Villarroel-Marín, A., Parsons, E.C.M., and Rose, N.A. (2007) Origin and development of whalewatching in the state of Aragua, Venezuela: Laying the groundwork for sustainability. Page 16-27 in Proceedings, 5th International Coastal \& Marine Tourism Congress, 11-15 September 2007, Auckland, New Zealand.
} 
opportunities for national capacity building. In recent years DIMAR has become interested in incorporating a marine mammal component in its cruises: since 2004 it has regularly invited marine mammal observers on its biannual cruises in Pacific waters of Colombia (HerreraCarmona, 2009; Palacios et al., submitted), and efforts to implement standardized data collection protocols on its Caribbean cruises are underway. Thus, future surveys will provide the necessary information for abundance estimation, population structure and management actions, all of which have been identified as research priorities at the national level (FlórezGonzález and Capella-Alzueta, 1995), as well as in the Action Plan for the Conservation of Marine Mammals in the Wider Caribbean Region (UNEP, 2008).

\section{Acknowledgements}

The American institution sponsoring the Siben and Odyssey expeditions in Colombian waters was the nonprofit Long-term Research Institute, now operating as the Ocean Alliance (Lincoln, MA). Its Colombian counterparts were the Grupo para las Investigaciones Submarinas (Cartagena) and the group Seguimiento de Corazón de Ballenas Vía Satélite (Bogotá). The catalysts of these expeditions were R. Payne, I. Kerr, J. Reynolds, A. Vélez-Sierra, J.S. Uribe, A. Vejarano, M. Obregón, and F. Ospina-Navia. Participants for Colombia included D.F. Torres, C. Obregon, F. Trujillo, P.L.R. Brennan and D.M. Palacios. We thank the other scientists on board and the office support staff, including T. Lyrholm, L. Galley, B.J. Brennan, and K. Marshall-Tilas. Participants in the R/V Malpelo cruises were S. Beltrán-Pedreros (1990, by invitation from $\mathrm{CIOH}$ Navy Captain J. Aguilera) and A. Mejía-Fajardo (2008). Logistic and financial support for the cruises was provided by the Interpolar Research Society, DIMAR/CIOH, and the Universidad Jorge Tadeo Lozano - Seccional Cartagena. M.A. Pardo was supported during the preparation of this manuscript by a grant from the Consejo Nacional de Ciencia y Tecnología (Ciencia Básica 2009 No. 691211 to E. Beier at CICESE) and by a Grant in Aid of Research from the Society for Marine Mammalogy. Comments from J. Bolaños-Jiménez and an anonymous referee helped improve an earlier version of this manuscript.

\section{References}

ACEVEDo-GALINDO, R. (2007) Potential geographical distribution of seven species of marine cetaceans reported in Venezuela, southeast Caribbean. Acta Zoológica Sinica 53: 853-864.

Caldwell, D.K., Caldwell, M.C., Rathjen, W.F. and Sullivan, J.R. (1971) Cetaceans from the Lesser Antillean Island of St. Vincent. Fishery Bulletin 69(2): 303-312.

Erdman, D.S., Harms, J. and Flores, M.M. (1973) Cetacean records from the northeastern Caribbean region. Cetology 17: 1-14.
Flórez-GonZÁlez, L. ANd CAPella-Alzueta, J. (1995) Mamíferos acuáticos de Colombia. Una revisión y nuevas observaciones sobre su presencia, estado del conocimiento y conservación. Informe del Museo del Mar (Universidad Jorge Tadeo Lozano, Bogotá Colombia) 39: 1-29.

Fraija, N., Flórez-González, L. and Jáuregui, A. (2009) Cetacean occurrence in the Santa Marta region, Colombian Caribbean, February-May 2007. Latin American Journal of Aquatic Mammals 7(1-2): 69-73.

Gero, S., Gordon, J., Carlson, C., Evans, P. and Whitehead, H. (2007) Population estimate and inter-island movement of sperm whales, Physeter macrocephalus, in the eastern Caribbean Sea. Journal of Cetacean Research and Management 9(2): 143-150.

Gordon, J., Moscrop, A., Carlson, C., Ingram, S., Leaper, R., Matthews, J. AND Young, K. (1998) Distribution, movements and residency of sperm whales off the commonwealth of Dominica, eastern Caribbean: Implications for the development and regulation of the local whalewatching industry. Report of the International Whaling Commission 48. SC/49/O. [Available from the International Fund for Animal Welfare, Yarmouth Port, MA, USA, <http://www.ifaw.org/ Publications/Program_Publications / Whales / asset_upload_file215_14458.pdf>].

GrigG, E. AND Markowitz, H. (1997) Habitat use by bottlenose dolphins (Tursiops truncatus) at Turneffe Atoll, Belize. Aquatic Mammals 23(3): 163-170.

JEFFERSON, T.A. (1996) Estimates of abundance of cetaceans in offshore waters of the northeastern Gulf of Mexico. The Southwestern Naturalist 41(3): 279-287.

JeFFERSON, T.A. AND LyNn, S.K. (1994) Marine mammal sightings in the Caribbean Sea and Gulf of Mexico, Summer 1991. Caribbean Journal of Science 30(1-2): 83-89.

KerR, A.K., Defran, R.H. and Campbell, G.S. (2005) Bottlenose dolphins (Tursiops truncatus) in the Drowned Cayes, Belize: Group size, side fidelity and abundance. Caribbean Journal of Science 41(1): 172-177.

Herrera-Carmona, J.C. (2009) Distribución y abundancia relativa de cetáceos en el Pacífico colombiano y su relación con las condiciones oceanográficas. M.Sc. Thesis. Universidad del Valle, Cali, Colombia. 150 pp.

Mejía-Fajardo, A. (2009) Relación de la presencia de cetáceos sobre la huella del satélite Jason-1 en el Caribe colombiano con las condiciones oceanográficas imperantes durante el segundo periodo de 2008. M.Sc. Thesis. Universidad Jorge Tadeo Lozano, Facultad de Ciencias Naturales. Santa Marta, Colombia. 179pp.

Mignucci-Giannoni, A.A. (1998) Zoogeography of cetaceans off Puerto Rico and the Virgin Islands. Caribbean Journal of Science 34(3-4): 173-190.

Mignucci-Giannoni, A.A., Swartz, S.L., Martínez, A., Burks, C.M. AND WATKINS, W.A. (2003) First records of the pantropical spotted dolphin (Stenella attenuata) for the Puerto Rican Bank, with a review of the species in the Caribbean. Caribbean Journal of Science 39(3): 381-392.

Muluin, K.D., Hoggard, W. And Hansen, L.J. (2004) Abundance and seasonal occurrence of cetaceans in outer continental shelf slope waters of the north-central and northwestern Gulf of Mexico. Gulf of Mexico Science 1: 62-73. 
Palacios, D.M., Gerrodette, T., Herrera, J.C., García, C., Soler, G.A., Ávila I.C., Bessudo, S., Hernández, E., Trujillo F., FlórezGONZÁlez, L. AND KeRr, I. (Submitted) Cetacean distribution and relative abundance in Colombia's Pacific EEZ from survey cruises and platforms of opportunity. Journal of Cetacean Research and Management.

Pardo, M.A. AND Palacios, D.M. (2006) Cetacean occurrence in the Santa Marta region, Colombian Caribbean, 2004-2005. Latin American Journal of Aquatic Mammals 5(2): 129-134.

Pardo, M.A., Jiménez-Pinedo, C. and Palacios, D.M. (2009) The false killer whale (Pseudorca crassidens) in the southwestern Caribbean: First stranding record in Colombian waters. Latin American Journal of Aquatic Mammals 7(1-2): 63-67.

PerRIN, W.F. (2002) Stenella frontalis. Mammalian Species 702: 1-6.

Romero, A., Agudo, A.I., Green, S.M. and Notarbartolo-DiSCIARA, G. (2001) Cetaceans of Venezuela: Their distribution and conservation status. National Oceanic and Atmospheric Administration Technical Report National Marine Fisheries Service 151: 59pp. [Available from the NMFS Scientific Pulbication Office, <http://spo.nwr.noaa.gov/trlist.htm>].

Romero, A., Hayford, K.T., Romero, A. And Romero, J. (2002) The marine mammals of Grenada, W.I., and their conservation status. Mammalia 66(4): 479-494.

Swartz, S.L., Cole, T., McDonald, M.A., Hildebrand, J.A., Oleson, E.M., Martinez, A., Clapham, P.J., Barlow, J. and Jones, M.L. (2003)
Acoustic and visual survey of Humpback Whale (Megaptera novaeangliae) distribution in the eastern and Southeastern Caribbean Sea. Caribbean Journal of Science 39(2): 195-208.

TARUSKI, A.G. AND WinN, W.H. (1976). Winter sightings of odontocetes in the West Indies. Cetology 22: 1-12.

UNEP (2008) Action plan for the conservation of marine mammals (MMAP) in the wider Caribbean region. United Nations. 39pp. [Available from <http://www.cep.unep.org/>].

VIDAL, O. (1990) Lista de los mamíferos acuáticos de Colombia. Informe del Museo del Mar (Universidad Jorge Tadeo Lozano, Bogotá, Colombia) 37: 1-18.

WARd, N., Moscrop, A. AND CARlson, C. (2001) Elements for the development of a marine mammal action plan for the wider Caribbean: A review of marine mammal distribution. United Nations Environment Programme - First Meeting of the Contracting Parties (COP) to the Protocol Concerning Specially Protected Areas and Wildlife (SPAW) in the Wider Caribbean Region 24-25 September, Havana, Cuba. 84pp. [Available from the United Nations Environmental Programme, Caribbean Environmental Programme <http:// www.cep.unep.org/>].

Weller, D.W., WÜRSIG, B., LynN, S.K. AND Schiro, A.J. (2000) Preliminary findings on the occurrence and site fidelity of photo-identified sperm whales (Physeter macrocephalus) in the northern Gulf of Mexico. Gulf of Mexico Science 18:35-39. 